\title{
REVIEW
}

\section{Zimbabwe: Injustice and Political Reconciliation}

Brian Raftopoulous and Tyrone Savage (eds)

Institute for Justice and Reconciliation

\section{INTRODUCTION}

The book consists of 15 chapters written by academics and professionals who have written widely on Zimbabwe. Most of them are either Zimbabwean citizens or have been involved in Zimbabwe in their professional careers. Their previous work on Zimbabwe gives their interpretation of the situation more weight. Brian Raftopoulos, who sets the tone of the book, attributes the current problems in Zimbabwe to a reconciliation policy that was a compromise between the liberation movement, the colonial power and the settler elite. He indicates that at independence the newly elected Prime Minister, Robert Mugabe, made reconciliation statements which never translated into action given the contours of the political landscape in the early years of the new state.

\section{About the Volume}

Chapter 1: The Promised Land: From Expropriation to Reconciliation and Jambanja LLOYD SACHIKONYE (pp 1-18)

The first chapter looks at the land question in Zimbabwe, tracing it from the 1800s to the present time. Land commissions are said to have been responsible for the land expropriation throughout the entire period. The author argues that contrary to the commonly held perception that there would be reconciliation after independence, reconciliation seems to have been a distant mirage in Zimbabwe. This has in part been because the importance of dealing with past injustices has been overlooked. The author also brings up an equally important issue of economic reconciliation, which was not addressed in Zimbabwe at independence in 1980. The British government's failure to keep its side of the bargain after the Lancaster House negotiations in terms of support for the redistribution process is also ably discussed. The recent land occupations are attributed to Britain's abdication of responsibility.

Chapter 2: Memories of Underdevelopment: A Personal Interpretation of Zimbabwe's Economic Decline

ROB DAVIES (pp 19-42)

The costs of economic decline in Zimbabwe is looked at in terms of three distinct periods: 1980-1990; 1990-1997 and 1997 to date. While this discussion is limited by 
a lack of empirical evidence to substantiate some views raised about the country's economic morass, the author has managed to depict the situation and to make pertinent comments which provide grounds for further examination. Some important observations have been made, such as the presence of economic gains in the 1980s, which lacked sustainability as opposed to gains in assets which would go a long way to sustaining the economy of post-colonial Zimbabwe. Put somewhat differently, the centralisation approach adopted by the government saw black people being given access to land but no title, thus leaving the title as the domain of the state. The situation presents contradictions where the government has now embarked on an aggressive land redistribution programme under the guise of redressing the past, yet at the same time destroying the future as the agricultural sector is stifled.

Chapter 3: 'Gukurahundi': The Need for Truth and Reparation SHARI EPPEL (pp 43-62)

Starting with a comparison of the Smith and Mugabe regimes the chapter draws a picture of how, even in a post-colonial condition, the country is increasingly returning to a one-party state in which the ruling party is not tolerant of the opposition and orchestrates violence against its own people. Reference is made to the notorious Five Brigade, which was responsible for the massacres of many people, particularly in the Matebeleland Province. The author argues that the absence of truth about the massacres in the 1980s and political torture since 2000 has affected many Zimbabweans.

Chapter 4: Reintegration of Ex-Combatants Into Zimbabwean Society: A Lost Opportunity

PAUL THEMBA NYATHI (pp 63-78)

The important subject of the integration of ex-combatants into the national army is put under the spotlight in this chapter. The author points out that the failure not only successfully to integrate the ex-combatants but to rehabilitate them has come back to haunt ZANU-PF. This was witnessed when they forced Mugabe to offer them $Z \$ 50000$ each as compensation for their involvement in the liberation war. However, now the ruling party appears also to be benefiting from the situation, using the ex-combatants to fight its political battles. As the author puts it, the excombatants who were not integrated are being made to destroy the democracy they strove for. 
Chapter 5: Contextualising the Military in Zimbabwe Between 1999 and 2004 and Beyond

MARTIN RUPIYA (pp 79-98)

This chapter discusses the role of the army and its inability to maintain a neutral position, particularly since the 2000 referendum. The author, himself a retired senior army officer, has skilfully analysed the motive behind the army's involvement in politics that culminated in the military announcing its preferred candidates for the presidential election. The author establishes a link (and reasons for the close ties) between the army and ZANU-PF by explaining the Zimbabwe Defence Force's (ZDF) involvement in the Democratic Republic of Congo. While he acknowledges the importance of reforming the military, particularly in the post-colonial era, he stops short of emphasising this need in the case of post-conflict Zimbabwe when he discusses the army's future role. This important aspect should be highlighted in the discussion and lessons can be learned from countries such as Lesotho which have already embarked on this process.

Chapter 6: Whither Judicial Independence in Zimbabwe?

CHARLES GOREDEMA (pp 99-118)

In this chapter, the independence of the judiciary, a sacrosanct element of a democratic society, is questioned. In the author's view the absence of such independence is another factor that compounds Zimbabwe's political problems. Many of the cases brought before the courts of law in the recent past have been opposed by the ruling party and the judges have been threatened and forced to retire. A critical question that the chapter addresses is who should ensure that the government gives the judiciary the respect that it deserves.

Chapter 7: Liberating or Limiting the Public Sphere? Media Policy and the Zimbabwe Transition, 1980-2004

WALLACE CHUMA (pp 119-139)

Evidence points to the fact that the media have not been spared by the authoritarian arm of the government in Zimbabwe. State-media relations and the transitions that the media have gone through from the colonial era to recent times are discussed here. The argument raised is that as in the colonial period, when there was a clampdown on liberal voices, the post-independence media in Zimbabwe are experiencing government heavy handedness. Media have been silenced by the Access to Information and Protection of Privacy Act (AIPPA), which came into force in 2002. Under the AIPPA privately owned newspapers such as the Daily News and the Daily News on Sunday were closed down. 
Chapter 8: Reconciliation, Ethnicity and School History in Zimbabwe, 1980-2002 TERESA BARNES (pp 140-159)

The chapter introduces the debate on ethnicity, which is seen as one of the trigger factors for violent political conflict in Zimbabwe today. This is manifested in the relations between the two major ethnic groups, the Ndebele and the Shona. The discussion on this issue posits the commonly held view that the dichotomy between the two groups translated into the sour relations between the two main political parties, ZAPU and ZANU, that manifested in bloody conflicts in 1981. Also important in this chapter is the issue of historiography. Colonialist historiography was used for Zimbabwe even after independence. The author indicates that it was only recently, in 1991, that a new history, with which the majority of the people could identify, was written. The concluding note on this issue draws attention to the fact that, even so given, the nationalist history has created rivalry between black and white Zimbabweans, with the latter portrayed as evil.

Chapter 9: Nation, Race and History in Zimbabwean Politics BRIAN RAFTOPOULOS (pp 160-175)

No book about Zimbabwe would be complete without a comment on ideology and its contribution to the crisis there. The author of this chapter has demonstrated how the ruling party is using ideology to withstand pressure from within and outside the country. He also points out that ZANU-PF is desperately entrenching liberation history as a form of religious fundamentalism and using the state media in the process to advance its messages and gain political mileage. The ruling party has also employed a strategy of attacking opposition parties, especially the MDC, and alienating them from the people, particularly in the rural areas.

Chapter 10: The Worm and the Hoe: Cultural Politics and Reconciliation After the Third Chimurenga

ROBERT MUPONDE (pp 176-192)

This author draws a picture of an 'us and them' scenario between the ruling ZANU$\mathrm{PF}$ and the opposition MDC, each of whom is said to behave as a victim of the other in their quest for recognition and their hopes of winning the sympathy of the voters, who, ironically, are the real victims of the political tug-of-war between the two major political parties. The author demonstrates some of the complexities of reconciliation in Zimbabwe, using some vivid imagery. For instance, he quotes one poet who asked 'can the worm bask in amity with the hoe which only yesterday cut its spine into halves?' The other image employed to illustrate the magnitude of the task is that of the fox and the lamb - can they, the author asks, feed together? 
Chapter 11: Orphans of the Empire: An Analysis of Elements of White Identity and Ideology Construction in Zimbabwe

KARIN ALEXANDRA (pp 193-212)

The chapter discusses issues of citizenship in a country with many races. The dilemma of the white Zimbabweans in terms of how they need to respond to being alienated in the country of their birth is raised. In other words, the chapter brings up the frustrations that whites face daily in Zimbabwe and their consideration of whether or not to emigrate. Importantly, the chapter highlights the fact that the citizenship issue does not begin with the coming to power of a black-led government but that it has also been an issue between whites groups in the competition for power, with the Britons considering themselves to be more citizens than the whites from South Africa.

Chapter 12: 'Zimbabwe for Zimbabweans': Invisible Subject Minorities and the Quest for Justice and Reconciliation in Post-Colonial Zimbabwe JAMES MUZONDIDYA (pp 213-235)

The dilemma of white Zimbabweans in the wake of land occupations has received most of the media attention but this chapter draws attention to the dilemma of the other minority races in Zimbabwe, whose struggle to survive the citizenship politics in the past and today is discussed. The chapter argues that even as people talk about justice and reconciliation the minority races are not considered and end up facing the toughest conditions as the country grapples with contradictions in the process of justice and reconciliation caused by conflation of terms such as citizenship and nationality.

Chapter 13: Constitutional Reform as a social movement: A critical narrative of the constitution-making debate in Zimbabwe, 1997-2000

BRIAN KAGORO (pp 236-256)

The chapter touches on the need for constitutional reform to address specifically the most contentious issues such as the presidency, citizenship and land redistribution, which were not adequately addressed by the Lancaster House negotiations. At the core of this issue is the need for a multi-stakeholder approach to the constitution-making process which will provide healing for the victims and shape the future of the country.

Chapter 14: The church and reconciliation: A mission impossible? DEPROSE T MUCHENA (pp 257-270)

In the same line of argument on inclusiveness raised in the preceding chapter this chapter touches on the role played by the church and civil society organisations in 
the political problems of the country. The church is said to have played and to continue to play a critical role in striving to build peace and stability in Zimbabwe. Various activities of the church are explored and it is interesting to note that, as a result of the volatility of the situation, even the church is looked at suspiciously and many of its leaders are labelled enemies of the state.

Chapter 15: South African diplomacy and the crisis in Zimbabwe: Liberation solidarity in the $21^{\text {st }}$ century

IAN PHIMISTER (pp 271-290)

The last chapter deals with South Africa's foreign policy with regard to Zimbabwe. The author points out that there is a perception from the South African side that there is a general plan to destabilise the region so as to protect the whites' interests. Mugabe's defeat would therefore be the beginning of problems for South Africa as he is being used as a test-case by the West in its attempt eventually to remove other liberation movements, including the ANC.

\section{By way of conclusion}

The book's major strength is the frank, open and balanced manner in which the complex issues of justice and political reconciliation in Zimbabwe are discussed. It also succeeds in giving the larger picture in terms of the political history of the country, the state, non-state actors, external actors, political parties and the people in the context of Zimbabwe's colonial and post-colonial development. Much of the literature about Zimbabwe's recent political crisis fails to look at all the races and indicate how the situation affects them. Most of it dwells on situations in which blacks are victims and whites villains, or vice versa, as well as on ZANU-PF versus MDC, without analysing the situation to show that behind these 'whites versus blacks and ZANU- PF versus MDC' situations there are ordinary young and old people who long to belong to a peaceful country. While the importance of scientific analysis cannot be overlooked, readers should not be made to consider the Zimbabwean situation in terms of statistics and academic abstracts at the expense of understanding the reality. The authors featured in this book have attempted to tell the stories that transcend the statistics and academic sophistry.

VICTOR SHALE EISA 